\title{
The Analysis of the Possibility to Improve the Efficiency of Container Transport Via the Oder Waterway with the Use of the RIS System
}

\section{Analiza mogućnosti poboljšanja učinkovitosti kontejnerskog prijevoza plovnim putem rijeke Oder uporabom RIS sustava}

\author{
Piotr Durajczyk \\ Inland Navigation Office \\ Maritime University of Szczecin \\ Poland \\ E-mail: pdurajczyk@szczecin.uzs.gov.pl
}

\section{Summary}

The topic of this article is the analysis of the possibility to improve the efficiency of container transport in two layers via the Oder Waterway (pol. Odrzańska Droga Wodna ODW) with the use of the RIS system (River Information Service). Taking into account the fact that the number of containers shipped during one voyage depends mostly on the construction of the vessel on which they are transported and on the technical parameters of the waterway, especially transit depths and bridge clearances, the article presents the results of the analysis of inland vessels used for transporting cargo on the ODW (pol. Odrzańska Droga Wodna), which - in view of the current state of fleet - best accommodate container transport, i.e. pushed convoys consisting of one Bizon III pusher and two BP500 pushed lighters. Additionally, the study includes the probabilistic analysis of water levels, carried out based on historical data obtained from reliable water gauges during the 1990-2015 period by the Institute of Meteorology and Water Management, which determine navigation conditions. This allows for determining the probability of passage of a loaded vessel under certain critical bridges, i.e. bridges limiting the navigation due to their inadequate clearance and making it impossible to perform transport tasks on certain sections of the waterway. The further part of the article synthetically presents the possibility to utilise the RIS system (River Information Service) to support the captain's decisions during the loading and ballasting of the vessel, thereby making it more probable that a given pushed convoy would navigate under selected bridges during the navigation season. The RIS system is a dynamically developing system, especially in Poland, where in $\mathbf{2 0 1 3}$ the Lower Oder RIS pilot implementation was completed and in $\mathbf{2 0 2 0}$ the Lower Oder RIS (River Information Service) Full Implementation project is to be completed. This allows for the use of this innovative system, which combines a lot of elements that check the correctness of their results during operation which affects the overall reliability of the entire system, to support a number of activities, including improving the efficiency of container transport within the Lower Oder RIS area (River Information Service). This article is an attempt to analyse problems related to the probability of passage of a loaded vessel under certain critical bridges and the possibility to use the RIS system (River Information Service) to support the captain's decisions during the passage under those bridges. The article proves on a theoretical basis that the use of the Oder Waterway for the transport of containers in significant quantities is highly probable, assuming adequate technical properties of the fleet and ports.

\section{Sažetak}

Tema je rada analiza mogućnosti poboljšanja učinkovitosti kontejnerskog prijevoza na dvjema razinama vodenim tokom rijeke Odre uporabom RIS sustava (Riječni informacijski servis). Budući da broj kontejnera koji se prevezu u jednom putovanju većinom ovisi o konstrukciji broda na kojemu se prevoze i tehničkim parametrima plovnog puta, posebice dubinama i prolazima ispod mostova, u radu iznose se rezultati analize brodova unutarnje plovidbe koji se koriste za prijevoz tereta iz ODW-a (Odrzańska Droga Wodna), kojije-imajući u vidu trenutno stanje flote - najpovoljniji za kontejnerski prijevoz, odnosno gurane konvoje koji se sastoje od jednog Bizon III gurača i dvije BP-500 gurane barže. Osim toga, rad uključuje vjerojatnu analizu vodenih razina, koja je provedena na temelju povijesnih podataka dobivenih od pouzdanih mjerača razine vode u razdoblju 1990. - 2015., koje je prikupio Institut za meteorologiju i upravljanje vodama (Meteorology and Water Management), a koji određuju uvjete plovidbe. Tako je moguće odrediti vjerojatnost prolaska nakrcanog broda ispod pojedinih mostova, tj. onih koji ograničavaju plovidbu uslijed nedovoljne visine prolaza ispod mosta, zbog čega nije moguće obaviti prijevoz na pojedinim dionicama plovnog puta. U radu se nadalje sintetički predstavlja mogućnost uporabe RIS sustava, kojim se potvrđuje odluka kapetana broda tijekom ukrcaja i balastiranja broda, povećavajući mogućnost da će gurani konvoj ploviti ispod pojedinih brodova u plovnoj sezoni. RIS sustav jest sustav koji se
DOI 10.17818/NM/2020/3.3

UDK 656.073.235

656.6

Original scientific paper / Izvorni znanstveni rad

Paper accepted / Rukopis primljen: 22. 4. 2020.

\section{KEY WORDS}

RIS system (River Information

Service)

Inland navigation

the Oder Waterway

containers

\author{
KLJUČNE RIJEČI \\ RIS sustav (Riječni informacijski servis) \\ unutarnja plovidba \\ plovni put rijeke Odre \\ kontejneri
}


dinamički razvija, posebice u u Poljskoj, gdje je 2013. izvršena pilot-primjena RIS sustava na donjem toku rijeke Odre, a 2020. dovršit će se projekt njegove potpune primjene na donjem toku Odre. Time će se omogućiti uporaba ovoga inovativnog sustava, koji kombinira niz elemenata kojima se provjerava točnost rezultata tijekom operacije, što utječe na ukupnu pouzdanost cijeloga sustava, kako bi se potpomoglo obavljanje niza aktivnosti, uključujući poboljšanje učinkovitosti kontejnerskog prijevoza u RIS predjelu donjeg toka rijeke Odre. Ovaj rad pokušaj je analize problema povezanih s mogućnošću prolaza nakrcanog broda ispod pojedinih kritičnih mostova te uporabe RIS sustava kao podrške odlukama kapetana tijekom prolaza ispod brodova. Teorijski je potvrđeno da je uporaba vodenog puta rijeke Odre za prijevoz kontejnera u značajnim količinama vrlo moguća, pod uvjetom postojanja prikladnih tehničkih mogućnosti flote i luka.

\section{INTRODUCTION / Uvod}

The profitability of inland container transport is primarily determined by the reliability and timeliness of the transport service provided. This is due to the fact that inland navigation is one of the most cost-effective means of transport, especially if the transport costs include external costs of transport (e.g. congestion, noise, accidents, environmental pollution).

The possibility of transporting cargo via inland navigation is largely determined by the operational parameters of waterways, which depend mainly on the class of the river. Required parameters for each class are described in detail in the Regulation of the Council of Ministers of 7 May 2002 on the classification of inland waterways (Journal of Laws Dz. U. 2002 No 77, item 695). Those parameters are, however, purely theoretical as in many places the requirements have not been met, which has been proven by multiple analyses (e.g. reports of the Supreme Audit Office). Hence a number of academic papers concern the limitations of providing inland waterway transport due to poor technical condition of waterways (Ekiert 1981a; Ekiert 1981b; Woś 2005; Kulczyk \& Skupień 2010; Ecorys 2011; Najwyższa Izba Kontroli 2014; Wojewódzka-Król \& Rolbiecki 2014; Pluciński 2016). But even in countries with wellmaintained waterways, inland navigation is hardly ever used to transport cargo in cities. New studies (Janjevic \& Ndiaye 2014, Beyer 2018, Steniusl et al 2018) stipulate the use of inland transport for urban freight transport as waterways are the only infrastructure with free capacity and no issues of congestion or traffic jams. Also officially adopted strategies of European Union (e.g. White Paper European Transport Policy for 2010) stress the need of modal shift in European transport.

Contrary to other EU countries, Poland has virtually no containerized cargo transport by inland waterways (GUS 2015, Kulczyk \& Skupień 2010, Woś 2005, Hann \& Woś 2016) and that is despite the fact that the first attempts to transport containers (standard, type 1C) from Polish inland ports took place as early as 1979. In his article (Krautwald 1981) the author describes the results of practical tests for the transport of containerized cargo on the ODW using vessels that are still in service today. The author also indicates that a pushed convoy, consisting of a pusher and two BP-500 barges, is the most suitable for transporting containers on the ODW. Subsequent studies from 2010 (Kulczyk \& Skupień 2010) justify using container transport along the Oder River from an economic standpoint.

It is a widely held opinion that the transport of cargo in two layers (which determines the profitability of transport) is not possible due to low bridges (Pluciński 2016), even though in 2014 a research experiment was conducted - the so-called "truth cruise", whose purpose was to prove that the transport of two layers of containers on the Oder Waterway is possible. However, the results of this experiment were considered disputable by the navigation community, mainly due to the desire to upgrade the
ODW class. The critics have argued that the "truth cruise" was carried out only once, at a selected time of year, with a favourable attitude of the waterway administration, which, for example, enabled the vessel to overcome bottlenecks and thus complete the cruise thanks to additional, non-standard water discharges.

The need and possibilities to include inland navigation within the intermodal transport chain are a subject of many publications (Rosa 2013; Wojewódzka-Król \& Rolbiecki 2013; Jacyna (ed.) 2012; Mindura (ed.) 2014, Janjevic \& Ndiaye 2014, Quak 2008), in which the authors enumerate the advantages of inland water transport and present its role in transport system. The need of harmonization of river information services (RIS) in order to ensure the safe and unbureaucratic movement of cargo and passengers along European waterways was stressed by many experts (e.g. PIANC Report 2019, Panteia 2014, Turner 2015, Van der Burgt et al. 2015).

One of the few publications on probability analysis and reliability testing methods in water and inland waterway transport (Gucma 2013) presents the problem of collisions of vessels with bridges in detail. In addition, the author presents the risk analysis of a vessel collision with bridges, risk assessment and criteria for its acceptability as well as models and methods used to estimate the probability of a vessel collision with a bridge. The conclusion about the need to forecast container transport conditions on the ODW, based on statistics of water levels, is presented in a monograph (Hann \& Woś 2016).

In addition to works aimed at improving the technical parameters of the waterway, activities are carried out to improve the efficiency and safety of inland waterway transport. In 2013, a pilot system of harmonized river information services (RIS) was implemented on the Lower Oder, which allows for better organization and management of transport on inland waterways and optimization of the use of existing fleet and infrastructure. Until now, however, there has been no comprehensive research on the possibility of using the already implemented system to improve the reliability of container transport by the Oder Waterway due to the passage of inland vessels under bridges.

The article is a synthetic summary of the research results of this issue for the Oder Waterway from Kędzierzyn-Koźle to Szczecin, described in detail in the doctoral dissertation entitled "Probabilistic analysis of a transport system using two layers of containers via the Oder Waterway (ODW) with the use of the RIS system". In the above-mentioned doctoral dissertation, 6 variants of container masses were analysed:

- medium weight containers - $10.9 \mathrm{t}$,

containers lighter by 1 standard deviation from the average $-7.9 t$, containers heavier by 1 standard deviation from the average - $13.9 \mathrm{t}$ empty containers $-2.25 \mathrm{t}$,

very heavy containers $-24 t$, 
- optimum containers when the barge's draft is equal to the pusher's draft (for most bridges) - $20.94 \mathrm{t}$.

The article discusses the results of the analysis of containers with a medium weight, i.e. 10.9t.

\section{CHARACTERISTICS OF THE ODER WATERWAY / Karakteristike vodenog puta rijeke Odre}

The Oder Waterway, although it is the best developed waterway in Poland, in terms of its adaptation to navigation needs remains a shipping route of regional importance, with navigability class parameters from I (lowest regional class) to III (domestic navigation class) on the majority of its length. Only a few short sections of ODW (pol. Odrzańska Droga Wodna) have the highest classes IV and $V$, i.e. international shipping classes. In addition, the existing river infrastructure is not adapted to transport needs and, due to insufficient maintenance works, it is also prone to damages.

The following table shows the technical requirements for waterways of particular classes. It should be emphasized, however, that many sections of the Oder Waterway, despite having a certain navigability class, do not meet all the technical parameters resulting therefrom (e.g. in the Szczecin Water Junction, the Oder River has the highest class - Vb, excluding the railway bridge in Podjuchy, which does not meet the requirements of minimum clearance under the bridge).

The analysed section of the Oder River, i.e. from KędzierzynKoźle to the marine port in Szczecin, due to the diversity of structures and operational parameters, can be divided into the following navigation sections:

- Channelised Upper Oder (from Kędzierzyn-Koźle [km 95.6] to Brzeg Dolny [km 282.6]), where the Odra River is crossed by 23 barrages located on the main shipping route. On this section, a transit depth of $1.8 \mathrm{~m}$ is provided throughout the entire shipping season.

- $\quad$ Free-flowing Middle Oder (from Brzeg Dolny [km 281.6] to the mouth of the Lusatian Neisse [km 542.4]), with difficult navigation conditions due to the smallest transit depths.

Free-flowing Middle Oder (from the mouth of the Lusatian Neisse [km 542.4] to the mouth of the Warta river [km 617.6]) - border section, where due to the poor condition of regulatory buildings there are numerous depositions lowering the transit depths, constituting navigation bottlenecks.

- Free-flowing Lower Oder (from the mouth of the Warta river [km 617.6] to Szczecin [km 739.9]), whose extension is the estuary section, called the "Sea Oder". This section of ODW can be further divided into the following sub-sections:

From Kostrzyn to Piasek [km 683], where the waterway has a variable course of the flow and numerous depositions,

Below $\mathrm{km}$ 683.0, where the groynes end and the conditions of the flow are dependent on the sudden decrease of the longitudinal slope,

Szczecin Water Junction (the West Oder, the East Oder, the Regalica, the Klucz-Ustowo Cutting), where the waterway has parameters of a waterway of international importance with some deviations.

Additionally, 61 bridges intersect the ODW on the analysed section. 14 of them can be considered dangerous because their clearance is less than $400 \mathrm{~cm}$ at HNWL'1.

Table 1 Operating parameters of inland waterways in Poland

Tablica 1. Radni parametri unutarnjih plovnih putova u Poljskoj

\begin{tabular}{|c|c|c|c|c|c|c|c|c|c|}
\hline \multirow[t]{2}{*}{ No. } & \multirow[t]{2}{*}{ Operating parameters } & \multirow[b]{2}{*}{ Class } & \multicolumn{7}{|c|}{ Parameter values } \\
\hline & & & la & $\mathrm{Ib}$ & II & III & \multirow[t]{2}{*}{ IV } & Va & $\mathrm{Vb}$ \\
\hline 1. & Minimum dimensions of the navigable route in the river & unit & & & & & & & \\
\hline 1.1 & navigable route width ${ }^{1)}$ & M & 15 & 20 & 30 & 40 & 40 & 50 & 50 \\
\hline 1.2 & transit depth ${ }^{2)}$ & M & 1.2 & 1.6 & 1.8 & 1.8 & 2.8 & 2.8 & 2.8 \\
\hline 1.3 & arc radius of the route axis ${ }^{3)}$ & M & 100 & 200 & 300 & 500 & 650 & 650 & 800 \\
\hline 2. & \multicolumn{2}{|l|}{ Minimum dimensions of a canal } & & & & & & \multicolumn{2}{|c|}{ 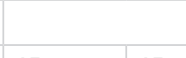 } \\
\hline 2.1 & width of the route ${ }^{1)}$ & M & 12 & 18 & 25 & 35 & 40 & 45 & 45 \\
\hline 2.2 & lowest water depth in the canal ${ }^{2)}$ & M & 1.5 & 2.0 & 2.2 & 2.5 & 3.5 & 3.5 & 3.5 \\
\hline 2.3 & bend radius of the route axis ${ }^{3)}$ & M & 150 & 250 & 400 & 600 & 650 & 650 & 800 \\
\hline 3. & \multicolumn{2}{|l|}{ Minimum dimensions of a lock } & & & & & & \multirow{3}{*}{$\begin{array}{l}12.0 \\
120\end{array}$} & \multirow[b]{2}{*}{12.0} \\
\hline 3.1 & width of the lock & M & 3.3 & 5.0 & 9.6 & 9.6 & 12.0 & & \\
\hline 3.2 & length of the lock & M & 25 & 42 & $65^{4)}$ & 72 & $120^{4)}$ & & 187 \\
\hline 3.3 & depth at the lower gate ${ }^{2)}$ & M & 1.5 & 2.0 & 2.2 & 2.5 & 3.5 & 4.0 & 4.0 \\
\hline 4. & \multicolumn{2}{|l|}{$\begin{array}{l}\text { Vertical distance of the conductors of overhead power } \\
\text { lines by normal overhang over HNWL } 5 \text { ) }\end{array}$} & & & & & & & \\
\hline 4.1 & $\begin{array}{l}\text { ungrounded of voltage under } 1 \mathrm{kV} \text { and grounded (regard- } \\
\text { less of voltage) and telecommunication wires }\end{array}$ & M & 8 & 8 & 8 & 10 & 12 & 15 & 15 \\
\hline 4.2 & $\begin{array}{l}\text { ungrounded with voltage over } 1 \mathrm{kV} \text {, depending on the } \\
\text { rated voltage of the line }(\mathrm{U})\end{array}$ & $M$ & $\begin{array}{l}U \\
10+ \\
150\end{array}$ & & $\begin{array}{l}U \\
12 \\
150\end{array}+$ & & $\begin{array}{l}U \\
14+-150\end{array}$ & $\begin{array}{l}U \\
17+---- \\
150\end{array}$ & \\
\hline
\end{tabular}

Notes:

1. The width of a navigable route at the level of the ship bottom with maximum capacity at full draft.

2. The depth refers to the first value of the ship draft, defined for the class in a table in attachment No 1

3. A route becomes wider at the bend depending on the length of the ship or pushed convoy and the radius of the bend.

4. Existing locks whose lengths amount to 56.6-57.4 m are included in Class II, and locks with the length of $85.0 \mathrm{~m}$ are included in Class IV.

Source: Council of Ministers Regulation of 7 May 2002 on the classification of inland waterways (Journal of Laws Dz. U. 2002, No 77, item 695 of 18 June 2002). 
Five representative critical bridges were selected for the analysis presented in the article:

1. Bridge in Kostrzyn - clearance by HNWL: $367 \mathrm{~cm}$

2. Bridge in Nietków - clearance by HNWL: $379 \mathrm{~cm}$

3. Bridge in Głogów - clearance by HNWL: $390 \mathrm{~cm}$

4. Bridge in Oława - clearance by HNWL: $372 \mathrm{~cm}$

5. Bridge in Opole - clearance by HNWL: $371 \mathrm{~cm}$

The critical bridges have been chosen according to the following criteria:

- Clearance under the bridge - the bridges with the lowest clearances were selected.

- Bridge location - selected bridges are located on different sections of the ODW (pol. Odrzańska Droga Wodna) on the Kędzierzyn Koźle-Szczecin route.

\section{RIS SYSTEM / RIS sustav}

River information services support inland waterway transport to make it a sustainable mode of transport. RIS improves the competitiveness of inland waterway transport and contributes to the overall objective of making inland waterway transport a safe, efficient and environmentally friendly link in the logistics chain (PIANC, 2018). It is a widely understood service packet, with various services that are aimed at optimizing traffic and transport flows.

There is no one commonly accepted definition of RIS in Europe. Each country decides to what extent it will implement the RIS system. For example, in case that ship reporting in inland navigation is required by national or international law, then also the Member State needs to support electronic reporting. In the present IWT market, ship reporting is not common but limited to certain operating areas and types of cargo. It is at present only obligatory for the Netherlands, Belgium, Germany, France (only Rhine river in container transport), Luxembourg (Mosel), Austria (only dangerous cargo) and Slovakia or Bulgaria and Poland are the only Member States not fulfilling all the requirements of the regulation for Notices to Skippers (NtS). ICEM (International Centre for Environmental Management) messages are not published in Belgium (all regions), France (French ports) and Luxembourg. WRM messages (water depths), which are also obligatory, are not published in Belgium (all regions) and France (French Ports) (Panteia, 2014). However, in accordance with Directive 2005/44/EC of the European Parliament and of the Council of 7 September 2005, RIS can be defined as harmonized information services supporting traffic and transport management in inland navigation

RIS (River Information Service) is an information system based on the harmonious interaction between three elements: devices, software and operators. The link connecting all these elements is a communication system, both wired and wireless ).

Thanks to this system, it is possible to increase the safety of navigation and its efficiency. RIS also modernizes the exchange of information between waterway administrators and users. RIS systems use common systems to connect pilots, transport companies, operators of lock, ports and terminals, RIS operators, and waterway administration and emergency services. They also allow better law enforcement and collection of statistical data and they facilitate the calculation of port fees and waterway toll charges.

Four basic technologies are used to provide RIS services (Ch. Plasil, 2011):
Vessel Tracking and Tracing [VTT], which makes it possible to supervise the safety of inland navigation, monitor water traffic and cooperate and provide information to relevant institutions and services (Kozłowski 2014, p. 3).VTT can be implemented at three technology levels (Durajczyk 2014, p. 13241):

- presentation of the current traffic image based on AIS data combined with an electronic navigation map and/or satellite images,

- enriching the current traffic image with additional data to facilitate the analysis of the situation,

comprehensive image analysis of traffic flows and thus ship traffic management.

- Notices to Skippers [NtS] is information collected and transmitted by water and navigation administration about the shipping route and traffic flows, water levels, river ice and weather. The obligation to develop and distribute NtS derives from the RIS Directive, which states that Member States "ensure that notices to skippers, including water level (or maximum allowable draught) and ice reports of their inland waterways, are provided as standardised, encoded and downloadable messages". NtS usually consists of two modules:

- an application enabling the preparation and publication of messages in accordance with standards,

- an internet service for captains and stakeholders that allows downloading and viewing messages issued by the administration.

- Electronic Ship Reporting in Inland Navigation [ERI] which is a system that allows you to quickly send information entered by skippers. This information may relate to cargo, vessel, travel route and crew personal data. Information obtained in this way can be used in various services.

Inland Electronic Chart Display and Information System [Inland ECDIS] - an electronic navigation system dedicated to inland shipping. The basis of this technology are inland electronic navigational charts, which, supplemented with additional data, e.g. on the movement and position of the vessel, support the skipper's decisions. Electronic navigational charts contain information on navigation signs, navigation obstacles, available transit depth, etc. Additionally, data displayed on dedicated devices can also be integrated with information obtained from the AIS system (Automatic Identification System) (e.g. movement of other ships), NtS navigation messages, hydrometeorological sensors, vessel's GPS data.

The following figure shows the diagram of the RIS system in Poland.

The RIS system was implemented in Poland only on a short, estuary section of the Oder River. The need to implement harmonized river information system on the Lower Oder by the end of 2013 resulted from the provisions of Directive 2005/44/ EC of the European Parliament of September 7, 2005. According to the directive, the member states of the European Union were obliged to implement the RIS system on all class IV (and higher) waterways if they connect with other waterways of the same standard. In Poland, only the lower section of the Oder River meets all these requirements, hence the obligation to implement the system. 


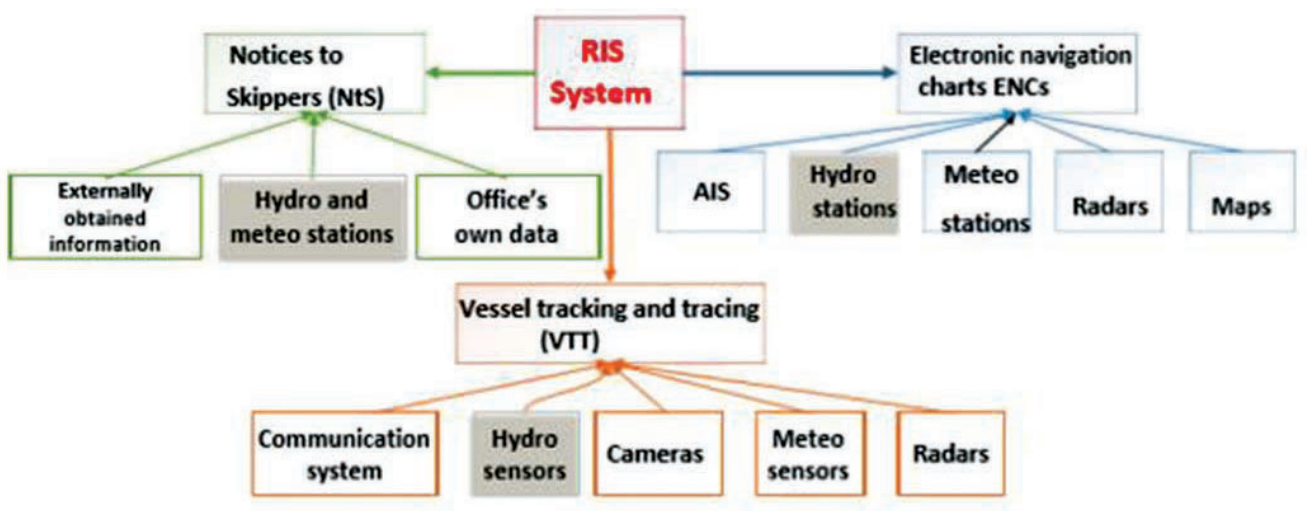

Figure 1 RIS system diagram in Poland Slika 1. Dijagram RIS sustava u Poljskoj

Source: author

\section{RESEARCH METHODOLOGY / Metodologija}

The aim of the research was to determine the reliability of container transport in two layers via the Oder Waterway and analyse the possibility to improve the probability of a vessel's passage under selected bridges by using the RIS system to support vessel's captain decisions during the loading and ballasting of the vessel.

A pushed convoy was selected for testing the transport system in two layers, which was structurally adapted for navigation on the Odra Waterway, i.e.:

- Bizon III pusher - a single-deck motor river pusher, which constitutes the basis of the Polish fleet. The unit of this type was designed over 50 years ago, in 1960s/1970s;

- two BP-500 barges - each barge allows the transport of up to 15 20-foot containers (type $1 \mathrm{C}$ ) in two layers. The nominal barge draft is $1.6 \mathrm{~m}$.

The following simplifying assumptions were adopted in the analysis:

- the draft of the vessel and its height above the water level (in the case of a barge measured with the load) is constant for the pusher, and for the barge it depends on the weight of the transported load and possibly on the use of ballasting system.

- the mass of cargo on one barge is the product of (assumed for a given vessel) the average container weight and the number of containers, i.e. 15.

To achieve this goal, a probabilistic method was chosen, which allowed for determining the probability of passage under certain critical bridges on the basis of statistical data obtained from reliable water gauges during the 1990-2015 period by the Institute of Meteorology and Water Management. The research was based on the reliability theory, with particular emphasis on Boolean algebra. The effect of research is calculating the probability of completing a transport task consisting in transporting containers in two layers via the Oder Waterway from Kędzierzyn-Koźle to Szczecin.

To perform the reliability analysis of the studied system, it was necessary to determine the following parameters:

- water level under the bridge (transit depth and clearance), vessel draft,

the height of the loaded pushed convoy above the water level, the value of the required depth reserve under the bottom of the ship and the height under the bridge structure, which allow to determine on the one hand the probability of collision of the upper layer of containers with the bridge span, and on the other hand - the probability of collision of a barge or pusher with the bottom of the river under the selected bridge. It should be emphasized that the paper adopted a simplification consisting in omitting the analysis of the probability of collision with bridge pillars (width of the waterway under the bridge).

To calculate the probability of both types of collisions, it was necessary to determine:

- bridge clearance,

- transit depth under the bridge,

the minimum clearance under the bridge required for the ship, the minimum waterway depth required for the ship.

Bridge clearances and transit depths for each bridge were calculated on the basis of statistical data obtained from reliable water gauges during the 1990-2015 period by the Institute of Meteorology and Water Management.

The transit depth was calculated as follows:

$$
h_{t}=h_{w}-p
$$

where:

$h_{t}$ - transit depth of a given section of the waterway,

$h_{w}$ - reading of a reliable water gauge for a given section of the waterway,

$\mathrm{p}$ - correction parameter for a given section of the waterway published by Regional Water Management Board.

To calculate the transit depth under the bridge, a simplification was adopted consisting in the use of a fixed correction factor $\mathrm{p}$ for a given section of the waterway (on which the critical bridge is located). The correction factors adopted for each of the critical bridges were obtained/calculated on the basis of data published on the websites of the Regional Water Management Boards in Szczecin, Wrocław and Gliwice ${ }^{2}$.

The clearance under the bridge was calculated as follows:

where:

$$
h_{m}=\left(h_{w w \dot{z}}-h_{w}\right)+h_{p w}
$$

$\mathrm{h}_{\mathrm{m}}$ - clearance under the bridge

$\mathrm{h}_{\text {wwz }}-\mathrm{HNWL}$ value for a given bridge

$h_{w}$ - reading of the water gauge for a given section of the waterway

$\mathrm{h}_{\mathrm{pw}}$ - clearance value for a given bridge at HNWL.

In addition, the clearance under the bridge was correlated with the value of the transit depth under the bridge:

$$
h_{m}=\left(h_{w w \dot{z}}-\left(h_{t}+p\right)\right)+h_{p w}
$$

${ }^{2}$ Data obtained 14 March 2017 


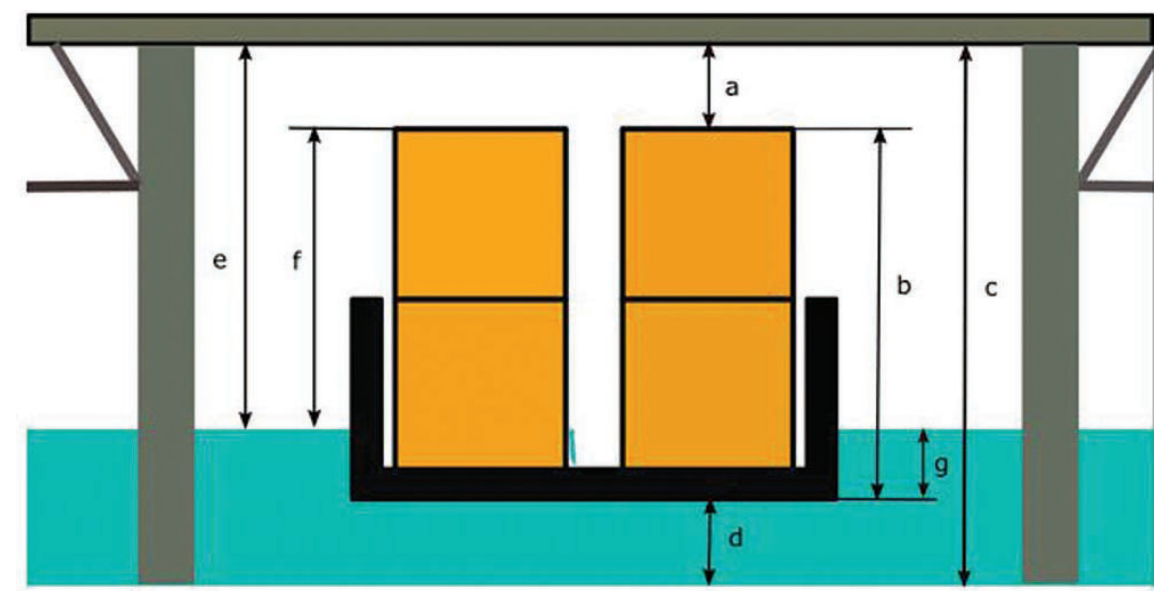

Notes:

a) Clearance between the top layer of the container and the edge of the bridge

b) Barge height with containers

c) Total height between the bottom and the edge of the bridge

d) The height of water between the bottom of the river and the lower edge of the barge

e) Height between the water surface and the edge of the bridge

f) The height of the ship above the water

g) Draft

Figure 2 Technical parameters of the bridge Slika 2. Tehnički parametri mosta

Source: author's own elaboration

Therefore:

$$
h_{t}=h_{p w}+h_{w w \grave{z}}+p-h_{m}
$$

where:

$\mathrm{h}_{\mathrm{m}}$ - clearance under the bridge

$h_{w w z}-$ HNWL value for a given bridge

$h_{t}$ - transit depth of a given section of the waterway

$\mathrm{p}$-correction parameter for a given section of the waterway

$\mathrm{h}_{\mathrm{pw}}$ - clearance value for a given bridge at HNWL.

Thanks to this, it was possible to reference the limiting parameters for which the barge will pass under the bridge (i.e. at the same time there will be no collision with the bottom and no collision with the bridge structure) through one value - transit depth. For instance: for the Bizon III pushed convoy and two BP500 barges with containers with an average weight of 10.9 tons to pass under the bridge in Nietków, the following conditions must be satisfied:

1. minimum water depth $-120 \mathrm{~cm}$ (Bizon III draft: $120 \mathrm{~cm}$; BP500 barge with 15 containers draft: $76 \mathrm{~cm}$ ),

2. the minimum clearance under the bridge for the barge $442 \mathrm{~cm}$ (which means maximum water depth of $315 \mathrm{~cm}$ ).

\section{THE RELIABILITY OF THE CONTAINER TRANSPORT SYSTEM / Pouzdanost sustava kontejnerskog prijevoza}

The profitability of inland container transport is primarily determined by the reliability and timeliness of the transport service provided. This is due to the fact that inland navigation is one of the most cost-effective means of transport, especially if the transport costs include external costs of transport (e.g. congestion, noise, accidents, environmental pollution). The only obstacle limiting the development of river transport in Poland is (at least in the more common opinion) its vulnerability to external factors that hinder or even prevent transport activities, and thus negatively affect the reliability of transport.
Due to the above, in order to assess the possibilities of commercial container transport on the Oder Waterway, it is necessary to determine the reliability of this process. In order to determine this reliability, especially when it comes to passing bridges, the following assumptions were made:

- length of a cruise from Kędzierzyn-Koźle to Szczecin - 1 week;

- navigation period - 8 months (March - October);

- number of weeks in the navigation period - 32;

- number of critical bridges - 5;

- number of vessels in the entire navigation period - 1920;

- system performance (capacity) - 58.000 containers/yearly navigation period.

Due to the above, the maximum number of convoys, i.e. pushed sets performing this task in weekly cruises is:

$$
F=\frac{W}{T \cdot 七}=\frac{58000}{32 \cdot 30} \cong 60
$$

where:

$F$ - maximum convoy size [pcs.],

$W$ - annual performance [containers/year],

$T$ - number of weeks in the navigation period,

$\measuredangle$ - capacity of one pushed convoy [number of containers].

It has been assumed that the convoy would only consist of vessels that would pass under critical bridges, which means that the size of the convoy would depend on navigation conditions (month) and the weight of the load carried.

The number of vessels that will not pass under a given bridge was calculated according to the following formula:

$$
n=\left(1-p_{i k}\right) \cdot F
$$

where:

$P_{i k}$ - probability of passage under $i$ bridge for a given vessel in the $k$ week of a given month,

$F$ - maximum convoy size [pcs.].

It has been assumed that in all weeks of one month the water level is constant and equal to the average for a given month. 
If the number of bridges is $m$, the total number of vessels that will not pass under the bridges amounts to:

$$
n_{m k}=F \cdot \sum_{i=1}^{i=m}\left(1-p_{i k}\right)
$$

The probability of such an event should be determined for the number of attempts to pass which is:

$$
P=m \cdot F
$$

hence:

$$
p_{i k}^{n}=\frac{n_{m k}}{P}=\frac{\sum_{i=1}^{i=m}\left(1-p_{i k}\right)}{m}
$$

This parameter determines the intensity of collisions in a given week of a given month.

$$
\lambda(t)=\frac{P[t, \Delta t]}{\Delta t}=\frac{\frac{f(t)}{R(t)} \Delta t}{\Delta t}=\frac{f(t)}{R(t)}
$$

Therefore the reliability of overcoming bridge obstacles in the following weeks of the sailing period amounts to:

$$
R(t)=1-\frac{1}{m} \sum_{k=1}^{k=T}\left[\sum_{i=1}^{i=m}\left(1-p_{i k}\right)\right]
$$

On this basis, the reliability of the Oder Waterway container transport process has been determined for vessels with medium-weight containers.

\section{RELIABILITY OF MEDIUM WEIGHT CONTAINER TRANSPORT / Pouzdanost prijevoza srednje teških kontejnera}

The analysis of available data shows that the greatest difficulties with the passage of pushed convoys with medium-weight containers occur under the bridges in Nietków, Kostrzyn and Opole. The observed difficulties, however, are present in different months. In Nietków they occur mostly in May and June, in Kostrzyn - in September and October, and in Opole
- in July, September and October. The results of the analysis are presented in the table below, which collects data on the number of vessels carrying containers with average mass that would not hypothetically pass in selected months under the selected critical bridges.

Table 2 Number of pushed sets with medium weight containers that would not pass under the critical bridges tested in selected months

Tablica 2. Broj guranih nizova srednje teških kontejnera koji ne bi prošli ispod kritičnih mostova testiranih u odabranim mjesecima

\begin{tabular}{|l|c|c|c|c|c|}
\hline \multicolumn{1}{|c|}{ Month } & \multicolumn{5}{|c|}{ Location (City/Town) } \\
\hline March & Nietków & Kostrzyn & Głogów & Oława & Opole \\
\hline April & 24.0 & 32.9 & 29.0 & 16.6 & 36.5 \\
\hline May & 39.6 & 15.8 & 13.9 & 14.2 & 31.2 \\
\hline June & 69.8 & 15.8 & 15.4 & 7.0 & 37.0 \\
\hline July & 84.5 & 20.4 & 19.9 & 8.6 & 58.6 \\
\hline August & 29.3 & 40.1 & 21.4 & 13.9 & 80.4 \\
\hline September & 42.7 & 94.6 & 53.0 & 21.1 & 74.4 \\
\hline October & 63.1 & 108.7 & 73.4 & 33.8 & 108.0 \\
\hline
\end{tabular}

Source: author

When considering the passage of a vessel in terms of overcoming all tested critical bridges for each month, the highest reliability of the transport process can be observed in April (90\%), May (88\%) and July (85\%), while the smallest is in September (68\%) and October (66\%).

In all months the results are better than for ships with empty containers. Detailed results for individual months are presented in chart 1.

In order to determine the reliability of the container transport process for the entire navigation period, the number of vessels carrying out the transport has been compared. The results of the analysis are presented in the chart below.

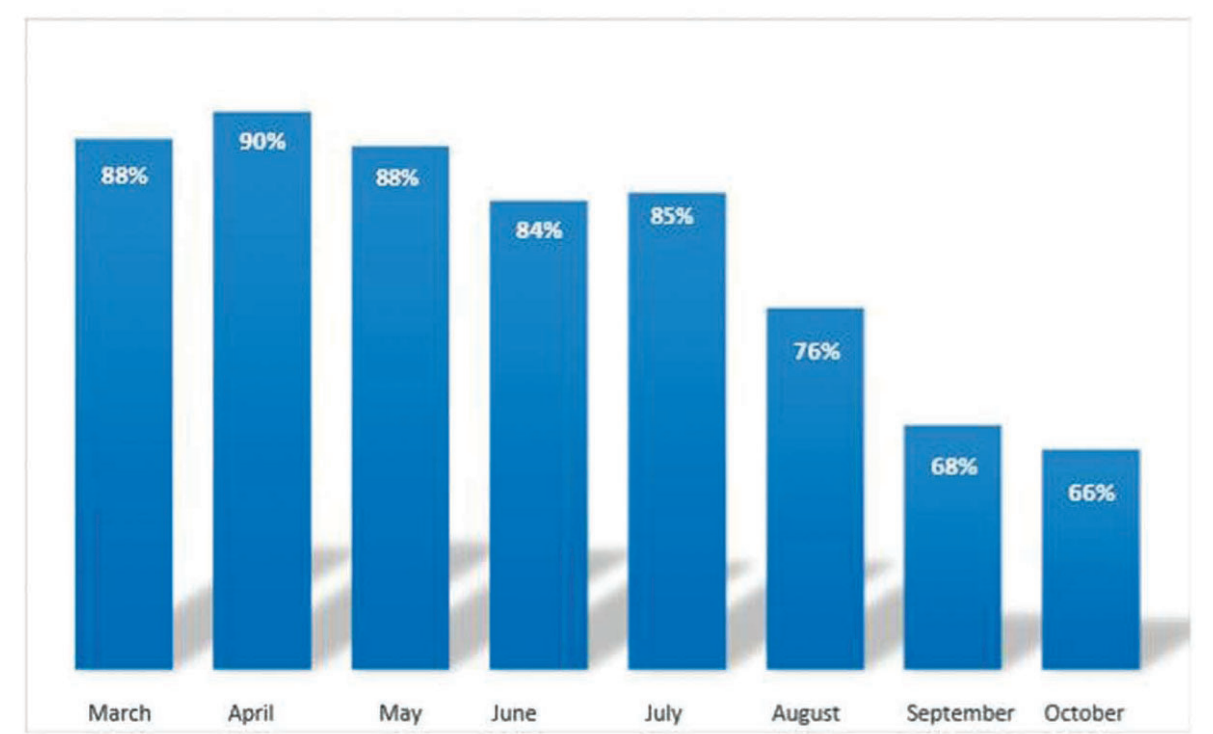

Chart 1 Reliability of passage of pushed convoys with containers of average weight under a group of critical bridges in individual months Grafikon 1. Pouzdanost prolaza guranih konvoja sa srednje teškim kontejnerima ispod skupine kritičnih brodova u pojedinačnim mjesecima Source: author 


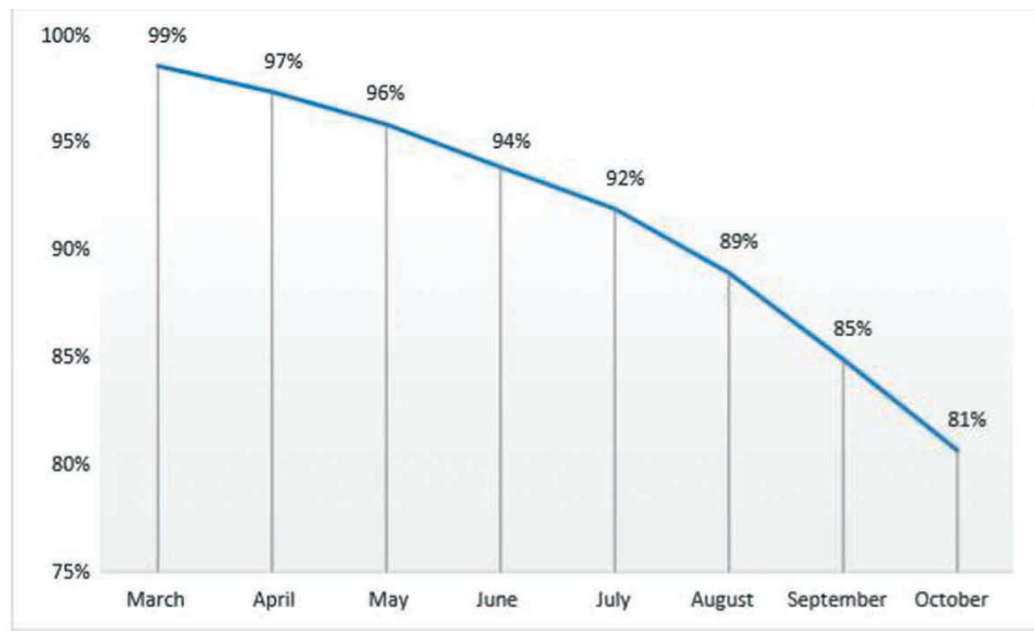

Chart 2 Reliability function for transporting medium-weight containers under critical bridges during the navigation season Grafikon 2. Pouzdanost prijevoza srednje teških kontejnera ispod kritičnih mostova u plovnoj sezoni

Source: author

The analysis of the intensity of collision probability of pushed convoys with medium-weight containers shows that this value is steadily increasing (excluding April and July) and amounts to the highest value in October. The analysis results are presented in the chart below.

The above analysis concerns the reliability of the transport process regardless of the cause of the potential failure. In case the navigation was conducted only during the two most favourable months, i.e. April and May, the risk of failure to complete navigation would only amount to $5 \%$ for an optimum vessel. For the period of five most favourable months (MarchJuly), the risk for the same pushed set would amount to $8 \%$, and for the entire navigation period analysed in this article $-16 \%$.

The results of the analysis are presented in the table and graph below.

where:

- Short season: April-May ;

- Medium season: March-July;

- Natural season: March-October;

Source: author

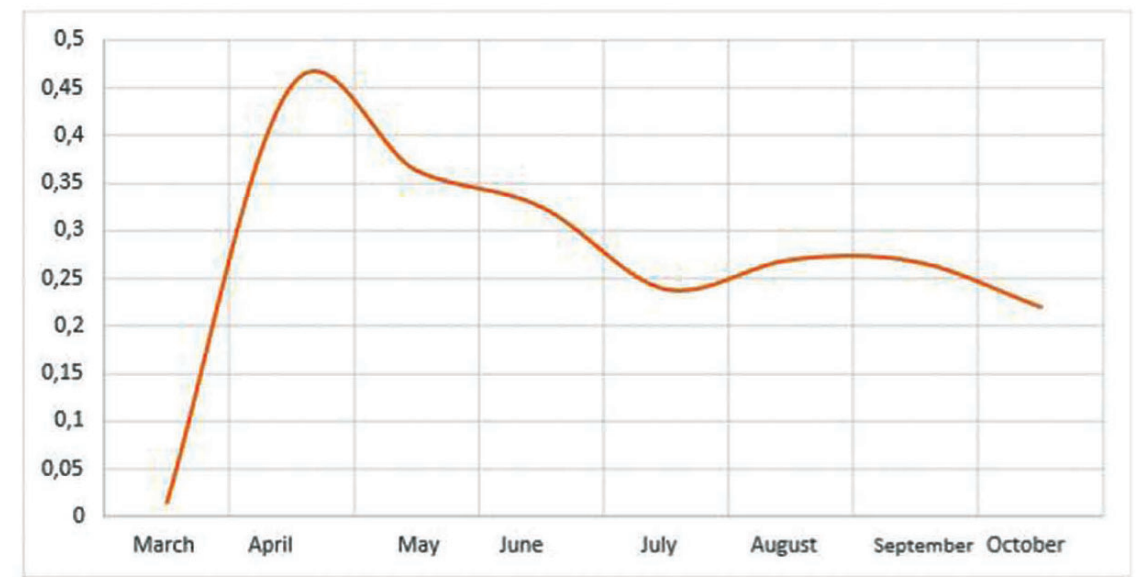

Chart 3 Analysis of collision probability of pushed convoys with medium-weight containers Grafikon 3. Analiza mogućnosti sudara guranih konvoja sa srednje teškim kontejnerima

Table 3 Analysis of ODW (pol. Odrzańska Droga Wodna) container transport depending on the length of the season and the pushed convoy Tablica 3. Analiza ODW (Odrzańska Droga Wodna) kontejnerskog prijevoza ovisno o duljini sezone i guranom konvoju

\begin{tabular}{|c|c|c|c|c|c|c|}
\hline \multirow[b]{2}{*}{ Navigation season } & \multicolumn{3}{|c|}{ Optimum convoy } & \multicolumn{3}{|c|}{ Medium convoy } \\
\hline & Short & Medium & Natural & Short & Medium & Natural \\
\hline $\begin{array}{l}\text { The average number } \\
\text { of pushed convoys in a } \\
\text { group }\end{array}$ & 56.74 & 55.18 & 50.59 & 53.5 & 52.24 & 48.39 \\
\hline $\begin{array}{l}\text { The number of } \\
\text { containers transported }\end{array}$ & 13,617 & 33,108 & 48,566 & 12,840 & 31,344 & 46,454 \\
\hline Degree of risk & $5 \%$ & $8 \%$ & $16 \%$ & $11 \%$ & $13 \%$ & $19 \%$ \\
\hline
\end{tabular}

Source: author 


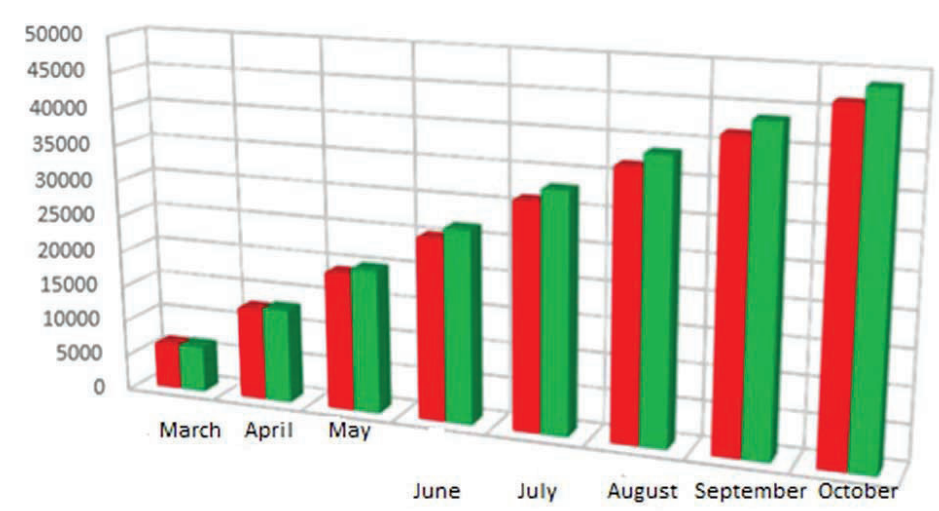

- medium containers =optimum containers

Chart 4 The number of containers transported via ODW (pol. Odrzańska Droga Wodna) depending on the length of the season and the average weight of the containers Source: author

Grafikon 4. Broj kontejnera koji se prevezu preko ODW-a s obzirom na duljinu sezone i prosječnu težinu kontejnera

The risk value depends on the weight of the transported cargo and the length of the navigation season. In the short season, the risk value is more than twice as high for a medium weight pushed convoy than for an optimal weight pushed convoy. The chart below presents a comparison of risk values for the analysed seasons and pushed convoys.

Parameters of the optimum vessel can be each time determined on the basis of data from the RIS system. Optimal vessel draft values can be achieved by ballasting the ship or adequately selecting the cargo. For a medium vessel to have an optimal draft, i.e. to be an optimum vessel, about $151 \mathrm{t}$ ballast is necessary. Some BP-500 barges are already equipped with a ballast system (depending on the vessel, up to 14 tanks of 8-10 tons each). In addition, you can still use the space between the bottom of the ship, where about 50 tons of ballast will fit.

In total, the ballasting capacity of such vessels can be estimated at $170 \mathrm{t}$. Also vessels which are currently not equipped with a ballasting system can be adapted for this purpose. Using the space between the vessel's sides and between the bottoms of the vessels, the vessel can be immersed to the required level.

To conclude collision intensity analysis has shown that, contrary to popular belief, the main problem in the container transport in two layers on the ODW is not the insufficient bridge clearance but the lack of adequate transit depth for navigation. The factors determining its capacity are the mass of cargo (which affects the vessel's draft and its height above the water) and the navigation period.

The most favourable period for navigation on the ODW from Kędzierzyn-Koźle to Szczecin is the first half of the navigation season, especially April and May. The collision intensity starts to rise in July. If the vessels navigated only in the most advantageous periods, the degree of risk would be much lower. In case the navigation tasks were conducted only during the two most favourable months, i.e. April and May, then the risk of failure to complete navigation by an optimum vessel (loaded according to data obtained from RIS) would only amount to $5 \%$, and for the container vessel of medium mass $(10,9 t)-6$ percentage points more, i.e. $11 \%$.

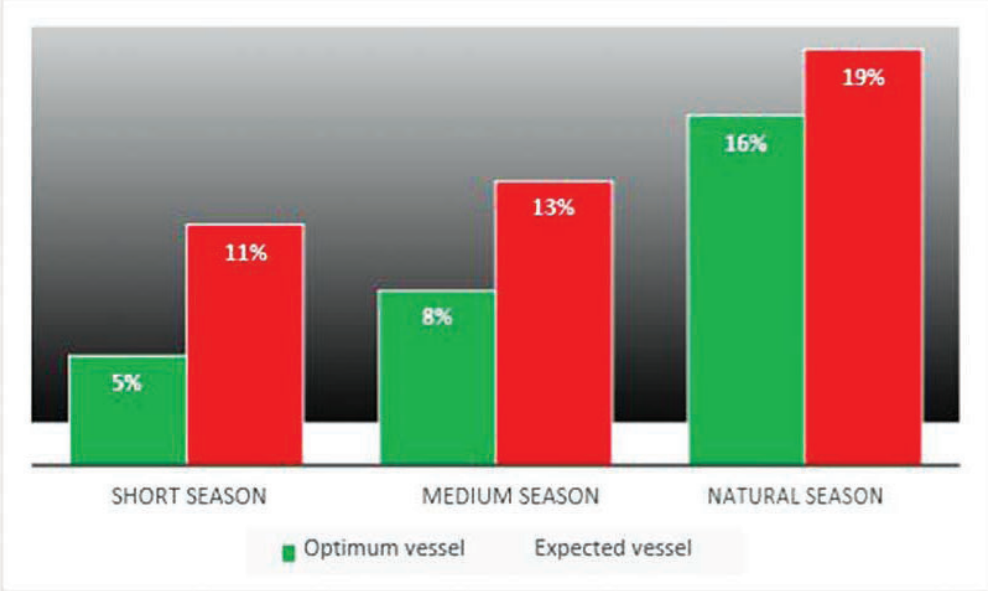

Chart 5 Analysis of the degree of risk of not completing the transport task depending on the length of the season and the weight of the load transported

Grafikon 5. Analiza stupnja rizika neizvršenja prijevoznog zadatka sobzirom na duljinu sezone i težinu tereta koji se prevozi Source: Durajczyk 2017, p:156 author's own elaboration 


\section{CONCLUSION / Zaključak}

The article proved on a theoretical basis that the use of the Oder Waterway for the transport of containers in significant quantities is highly probable, assuming adequate technical properties of the fleet and ports.

Contrary to popular belief, the main problem in the two-tier container transport on the ODW is not the insufficient bridge clearance but the lack of adequate transit depth for navigation. The factors determining its capacity are the mass of cargo (which affects the vessel's draft and its height above the water) and the navigation period.

The parameters of the optimal vessel can always be defined on the basis of RIS data. With RIS system it is possible to obtain real time data, via NtS, Inland ECDIS or VTT, on the current hydro and meteorological situation on the planned section of the waterway, which makes it possible to adjust both the loading of the vessel and the route selection in order to reduce the risks associated with clearance under bridges.

For depth, the limit value is the submersion of the Bizon III pusher, which is $110 \mathrm{~cm}$. The barge must transport containers with an average weight of $21 \mathrm{t}$ to achieve such immersion. In the study, the pushed convoy loaded with such containers was determined to be optimal.

Optimal draught values of the vessel can be achieved by ballasting the vessel or by appropriate selection of the cargo carried. For an average vessel to have the optimal draught, approximately $151 \mathrm{t}$ of ballast is necessary to be the "optimal vessel". Part of the BP-500 barges is already equipped with a ballast system (depending on the ship up to 14 tanks of 8-10 tons each). In addition, the space between the bottoms of the ship can still be used, where about 50 tons of ballast can be accommodated. In total, the ballast capacity of such vessels can be estimated at $170 \mathrm{t}$. Ships which do not currently have a ballast system can also be adapted for this purpose. Using the space between the sides of the vessel and between the bottoms of the vessel, the vessel can be submerged to the required level.

The analysis shows that the probability of carrying out the transport task on the Kędzierzyn-Koźle - Szczecin route is higher than for medium-weight containers. The analysis of collision intensity has shown that the most favourable period for navigation is the first half of the navigation season especially April and May. The intensity of collisions starts to increase rapidly at the beginning of July. Should navigation be conducted only in those favourable times, the risk of collisions would be much lower. If vessels were navigated only in the best months, i.e. April and May, then the risk of a failure of passage of an optimal vessel (loaded according to data provided by the RIS system) would be only $5 \%$, and the risk for a vessel with containers of an average weight if $10.9 \mathrm{t}$ would amount to $11 \%$, i.e. 6 pp more. The period of five favourable months (March-July) carries the risk of $8 \%$ for the optimal vessel, and for the convoy of an average weight of $10.9 \mathrm{t}$ it amounts to $13 \%$, i.e. 5 pp more.

\section{REFERENCES / Literatura}

[1] Beyer, A. (2018). "Inland Waterways, Transport Corridors and Urban Waterfronts". International Transport Forum Discussion Papers, OECD Publishing. Paris.

[2] Durajczyk, P. (2016). "Implementation of RIS in Poland. The current state and plans for future development". Autobusy. Technika, Eksploatacja, Systemy Transportowe, Vol. 17, No. 12, pp. 598-601.
[3] Durajczyk, P. (2014). "Korzyści z wdrożenia systemu informacji rzecznej RIS". Logistyka, No. 6, pp. 13241-13244.

[4] Ecorys (2011). Program rozwoju infrastruktury transportu wodnego śródlądowego w Polsce. Część 2. Propozycja.

[5] Ekiert, E. (1981).“Odrzańskie porty śródlądowe - Charakterystyka eksploatacyjnotechniczna budowli irządzeń przeładunkowych". Magazynowanie i transport towarów, No. 2.

[6] Ekiert, E. (1981). "Żegluga na Odrze i jej porty". Magazynowanie i transport towarów, No. 2.

[7] Evaluation of RIS Implementation for the period 2006-2011 (2014).

[8] Gucma, L. (2013). Zarządzanie ryzykiem w rejonie mostów usytuowanych nad drogami wodnymi w aspekcie uderzenia jednostek pływających. Szczecin: Wydawnictwo Naukowe Akademii Morskiej w Szczecinie.

[9] Hann, M., Woś, K. (2016). Żegluga odrzańska jako element intermodalnych łańcuchów transportowych. Szczecin: Wydawnictwo Naukowe Akademii Morskiej w Szczecinie.

[10] Inland Navigation Committee (InCom) (2018). Guidelines and Recommendations for River Information Services, Edition 4.

[11] Jacyna, M. (ed.) (2012). System Logistyczny Polski. Uwarunkowania techniczno-technologiczne komodalności transportu. Warszawa: Oficyna Wydawnicza Politechniki Warszawskiej.

[12] Janjevic, M., Ndiaye, A. B. (2014). "Inland waterways transport for city logistics: A review of experiences and the role of local public authorities". Urban Transport XX, pp. 279-290. https://www.witpress.com [accessed 24/7/2019] https://doi.org/10.2495/UT140241

[13] Kozłowski, M. (2014). Opracowanie wytycznych dla zagwarantowania wysokiej jakości usług VTT wraz ze zidentyfikowaniem potencjalnych odbiorców usług VTT i określeniem zasad wymiany danych. Techniczna i prawna analiza możliwości udostępnienia obrazu z kamer w sieci Web. Szczecin: Urząd Żeglugi Śródlądowej w Szczecinie.

[14] Krautwald, J. (1981). "Jednostki ładunkowe - ich przeładunki i przewozy środkami technicznymi żeglugi śródlądowej". Magazynowanie i transport towarów, No. 2.

[15] Kulczyk, J., Skupień, E. (2010). “Transport kontenerowy na Odrzańskiej Drodze Wodnej". Prace naukowe Politechniki Warszawskiej, Vol. 73, pp. 61-75.

[16] Kulczyk, J., Winter, J. (2013). Śródlądowy transport wodny. Wrocław: Oficyna Wydawnicza Politechniki Wrocławskiej.

[17] Masłowska, M. (2014). Analiza pilotażowego wdrożenia usług NtS w Polsce. Analiza oprogramowania Centrum RIS pod kątem możliwości wizualizacji komunikatów na elektronicznych mapach ECDIS. Szczecin: Urząd Żeglugi Śródlądowej w Szczecinie.

[18] Mindura, L. (2014). Technologie transportowe. Wydawca: Wydawnictwo Naukowe Instytutu Technologii Eksploatacji.

[19] Najwyższa Izba Kontroli (2014). Informacja o wynikach kontroli: Funkcjonowanie Żeglugi Śródlądowej. Warszawa.

[20] PIANC Secrétariat Général (2019). Pianc Report, No. 125: Guidelines and recommendations for River Information Services. Brussels.

[21] Plasil, Ch. (2011). "Managing geo-reference data within River Information Services - the RIS Index". Smart Rivers 2011, September 13-16, 2011, New Orleans, LA.

[22] Pluciński, M. (ed.) (2016). Możliwości wykorzystania transportu wodnego śródlądowego w obsłudze zespołu portowego Szczecin - Świnoujście. Szczecin: Polskie Towarzystwo Ekonomiczne Oddział w Szczecinie.

[23] Quak, H. (2008). Sustainability of Urban Freight Transport Retail Distribution and Local Regulations in Cities. Rotterdam: Erasmus Research Institute of Management (ERIM).

[24] Rosa, G. (2013). Konkurencja na rynku usług transportowych. Warszawa: Wydawnictwo C. H. Beck.

[25] Steniusl, I., Garmel, K., Hall Kihl, S., Burman, M. (2014). Waterway 365. System Analysis of Challenges in Increased Urban Mobility by Utilization of the Water Ways. KTH Royal Institute of Technology, TRITA-AVE 2014-13.

[26] Turner, M. (2015). "Paper 46 - DUKC Chart Overlay - An operational tool for vessel navigation". Smart Rivers 2015, 7-11 September 2015, Buenos Aires, Argentina.

[27] Van der Burgt, T., Şentürk, B., Wouters K. (2015). “Paper 66 - Shipborne Information Services". Smart Rivers 2015, 7-11 September 2015, Buenos Aires, Argentina.

[28] White Paper - European Transport Policy for 2010: Time to Decide (2001). Luxemburg: Office for Official Publications of The European Communities.

[29] Wojewódzka-Król, K., Rolbiecki, R. (2014). Transport wodny śródlądowy. Funkcjonowanie i rozwój. Gdańsk: Wydawnictwo Uniwersytetu Gdańskiego.

[30] Woś, K. (ed.) (2016). Założenia do Programu rozwoju śródlądowych dróg wodnych. Warszawa: Ministerstwo Gospodarki Morskiej i Żeglugi Śródlądowej. 